\title{
Lymphoblasts 5 Percent or More of Peripheral Blood White Cells
}

National Cancer Institute

\section{Source}

National Cancer Institute. Lymphoblasts 5 Percent or More of Peripheral Blood White

Cells. NCl Thesaurus. Code C156390.

A semi-quantitative microscopic finding indicating that 5 percent or more of the nucleated cells in a peripheral leukocyte sample are immature mononuclear cells of lymphoid origin. 